\title{
KONTRIBUSI SISTEM INFORMASI MAJANEMEN TERHADAP EFEKTIVITAS KERJA PEGAWAI BADAN PEMBERDAYAAN MASYARAKAT DAN PEMERINTAH DESA PROVINSI SULAWESI TENGGARA \\ Oleh: \\ La Tarifu ${ }^{1}$ \\ ${ }^{1,}$ Dosen Fakultas Ilmu Sosial dan Ilmu Politik Universitas Halu Oleo \\ latarifu123@gmail.com
}

\begin{abstract}
The purpose of this paper is to determine the contribution and influence of management information systems on the work effectiveness of employees in the Community Empowerment and Village Government Agency of Southeast Sulawesi Province.

This paper examines two variables, namely the independent variable is the influence of the Management Information System system which consists of dimensions: functionalization, integration, professionalism, quality, equity, coordination, while the employee work effectiveness dependent variable consists of three dimensions each: time measurement, yield size and cost size.

The research method used in this study is the explanatory survey. The population in this study were all Civil Servants at the Community Empowerment and Village Government Agency of Southeast Sulawesi Province, amounting to 93 people and a sample of 48 people representing each level of education, namely Senior High School, Bachelor / DIII, Bachelor, and Masters. The research variable is a management information system as an independent variable $(X)$ and employee work effectiveness is the dependent variable $(Y)$.

The results of the study indicate that there is a significant influence and there is a contribution of management information systems to the work effectiveness of employees at the Community Empowerment and Village Government Agency of Southeast Sulawesi Province. The biggest influence of the variables forming the management information system is the dimension of integration, and coordination, while the smallest dimension of the variables forming the management information system is the dimension of equity. The solution that needs to be developed is improving employee competencies through education and technical training in management information systems.
\end{abstract}

Keywords : Management Information System, Effectiveness of Employee's Work 


\section{PENDAHULUAN}

Pekerjaan informasi adalah pekerjaan yang meliputi pengumpulan data, penyebaran data dengan meneruskannya ke unit lain, atau langsung diolah menjadi informasi, kemudian informasi tersebut diteruskan ke unit lain. Pada unit kerja yang baru informasi tadi dapat langsung digunakan atau dapat juga dianggap sebagai data (baru) untuk diolah lagi menjadi informasi sesuai dengan keperluan unit yang bersangkutan (Amsyah Zulkifli, 2005). Dengan beredarnya informasi dari unit ke unit lain maka terjadilah arus informasi atau hubungan informasi antar unit. Hubungan tersebut lazim disebut sebagai hubungan antar subsistem dalam suatu kaitan kerjasama satu sistem. Dengan demikian timbullah istilah Sistem Informasi, karena sistem informasi tersebut dikerjakan dengan menggunakan prinsip-prinsip manajemen agar tujuan dapat tercapai secara efisien dan efektif, maka disebut Sistem Informasi Manajemen.

Sistem Informasi Manajemen bertugas menyediakan dan menyajikan informasi, diperuntukkan bagi pimpinan digunakan untuk pengambilan keputusan. Keputusan itu dapat berupa kebijakan ataupun tindakan yang berkenaan dengan fungsi-fungsi manajemen, yakni perencanaan, penggerakkan, pengorganisasian, koordinasi, supervisi, ketenagaan, pemantauan, kontrol dan penilaian (Amsyah Zulkifli, 2005). Keputusan-keputusan dalam fungsi-fungsi tersebut akan mempengaruhi kegiatan organisasi baik secara keseluruhan maupun secara sebagian-sebagian.

Peneliti melihat pentingnya secara internal Sistem Informasi Manajemen membantu bagian Kantor. Informasi dan Telekomunikasi dalam pengambilan keputusan-keputusan penting yang menyangkut kemajuan pelaksanaan proyek penyampaian sarana informasi bagi Badan Pemberdayaan Masyarakat dan pemerintahan Desa Provinsi Sulawesi Tenggara terutama yang berada di tempat-tempat terpencil, begitu pula dalam membantu para pegawai untuk memiliki pedoman kerja yang jelas dan tegas mengenai aturan kerja dalam hal membantu memahami wewenang dan tanggungjawab yang dimiliki oleh setiap pegawai dalam melaksanakan kerjanya.

Secara empirik masih sering terjadi permasalahan pada Kantor Badan Pemberdayaan Masyarakat dan Pemerintahan Desa Provinsi Sulawesi Tenggara, efektivitas kerja pegawai masih relatif rendah hal ini disebakan masing-masing bagian dan sub bagian mempunyai tugas pokok dan fungsi yang berbeda, dan belum memanfaatkan pentingnya penggunaan Sistem Informasi Manajemen sehingga dalam pelaksanaan tugas dan fungsi, juga masih terjadi keterlambatan di satu atau beberapa sub bagian dan berpengatuh terhadap kinerja pegawai.

Berdasarkan pengamatan penulis, bahwa dalam pelaksanaannya terdapat beberapa masalah sebagai berikut:

1. Laporan yang dihasilkan kurang akurat, akibat informasi yang di kelola tidak valid dan kesalahan data dan informasi yang di terima.

2. Tugas pokok dan fungsi masing-masing bagian sering dilaksanakan tidak sesuai dengan rencana yang ditentukan.

3. Pekerjaan kantor tidak efektif karena pegawainya banyak membuang waktu, diantaranya terlalu banyak menggunakan fasilitas komputer dan jaringan internet untuk kepentingan personal (bermain) dan masih meninggalkan pekerjaan dengan alasan istirahat atau melakukan kegiatan-kegiatan diluar tugas pokoknya.

Berbagai keterlambatan urusan dan pelayanan administrasi yang penulis amati, salah satunya disebabkan oleh faktor koordinasi antar bagian dan sub bagian. Permasalahan tersebut diduga akibat dari pelaksanaan Sistem 
Informasi Manajemen oleh pegwai di Badan Pemberdayaan Masyarakat dan Pemerintahan Desa Provinsi Sulawesi Tenggara belum berjalan secara efektif.

Berdasarkan latar belakang tersebut, maka penulis mencoba melakukan kajian dan analisis tentang "bagaimana kontribusi dan pengaruh Sistem Informasi Manajemen Terhadap Efektivitas Kerja Pegawai Badan Pemberdayaan Masyarakat dan Pemerintahan Desa Provinsi Sulawesi Tenggara"

\section{TINJAUAAN PUSTAKA}

\section{Konsep Sistem Informasi Menejemen (SIM)}

Murdick dan Ross (1971:109) mengemukakan bahwa Sistem informasi manajemen (SIM) adalah proses komunikasi di mana informasi masukan (input) direkam, disimpan dan diperoleh kembali (diproses) bagi keputusan (output) mengenai perencanaan, pengoperasian, dan pengawasan.

Dengan demikian bahwa sistem informasi manajemen merupakan suatu proses informasi yang terdiri dari masukan komunikasi yang diolah kemudian menjadi suatu keputusan yang dapat dilaksanakan kamudian dalam pelaksanaannya juga memerlukan adanya pengawasan agar dapat dilaksanakan dengan baik dan benar.

Secara teknis dijelaskan oleh Atmosudirjo (1985 : 158), menyatakan pengertian manajemen secara umum asebagai berikut : "Manajemen adalah pengendalian dan pemanfaatan semua factor dan sumber daya, yang menurut suatu perencanaan (planning) diperlukan untuk mencapai atau menyelesaikan suatu prapta (objective) atau tujuan kerja tertentu."

Pengertian di atas memiliki maksud bahwa tercapainya tujuan-tujuan dalam manajemen dan juga kelangsungan hidup sebuah organisasi tergantung pada adaptasi yang efektif terhadap lingkungan, yang berarti mengidentifikasi sebuah strategi untuk memasarkan outputnya, memperoleh sumber-sumber daya yang dibutuhkan dan menangani ancaman-ancaman eksternal. Adaptasi diperbaiki dengan mengantisipasi kebutuhan-kebutuhan dan keinginan-keinginan dari masyarakat, menilai tindakan-tindakan dan rencanarencana, mengevaluasi kemungkinan terjadinya hambatan-hambatan dan ancaman-ancaman.

Pandangan tentang organisasi dan manajemen menunjukkan bahwa organisasi itu adalah sistem yang terdiri dari subsistem-subsistem dan ditentukan oleh batas-batas yang dapat diidentifikasi dari suprasistem lingkungannya. Pandangan ini berusaha memahami berbagai saling hubungan di dalam dan di antara berbagai subsistem itu disamping di antara organisasi dengan lingkungannya dan menentukan pola hubungan atau konfigurasi dari variabel-variabel.

Pengertian tentang organisasi yang didasarkan pada berbagai hasil pengkajian yang mendalam berdasarkan pengalaman serta kondisi yang berbeda satu sama lain. Menurut Kast dan Rosenzweig (1990 : 21) mendefinisikan organisasi yaitu :

Organisasi berarti menstruktur dan memadukan (integrating) kegiatan, yaitu kegiatan orangorang yang bekerja bersama dalam hubungan yang saling bergantung. Paham saling berhubungan ini menunjukkan suatu sistem sosial. Oleh karena itu, kita dapat mengatakan bahwa organisasi itu terdiri dari (l) pengaturan yang berorientasi sasaran (goal oriented arrangements), orang dengan tujuan; (2) sistem psikososial, orang yang berinteraksi dalam kelompok; (3) sistem teknologis, orang yang memakai pengetahuan dan teknik; (4) integrasi kegiatan-kegiatan yang terstruktur, orang yang bekerja bersama dalam hubungan-hubungan yang berpola.

Dengan demikian bahwa organisasi merupakan suatu wadah tempat berkumpulnya dua orang atau lebih yang mempunyai tujuan bersama, dimana didalam organisasi tersebut mempunyai kegiatan-kegiatan yang terencana 


CC. Jounal publiuho is licensed under a Creative Commons Attribution 4.0 International License, which permits
unrestricted use, distribution, and reproduction in any medium, provided the original work is properly cited.

yang telah disusun dan harus dipatuhi baik yang bertindak sebagai pemimpin maupun sebagai anggota organisasi.

Catatanya dalah agar sistem organisasi tersebut dapat berfungsi, maka menurut Steers (1985 : 12) "memerlukan adanya tiga komponen dasar, yaitu masukan (input), proses dan keluaran (output). Masukan meliputi semua faktor yang diperlukan dari lingkungannya termasuk dana, sumber daya manusia, perangkat keras dan lunak dan hal-hal lain yang dianggap perlu. Masukan tersebut kemudian diolah melalui proses. Dalam proses tersebut diperlukan adanya metode-metode. Metode-metode diperlukan sehingga menghasilkan keluaran. Keluaran tersebut dirasakan oleh lingkungannya, dan selanjutnya lingkungan akan memberikan umpan balik.

Maka logika berpikir yang harus di bangun adalah bagaimana Sistem Informasi Manajemen dapat berperan untuk menghasilkan informasi yang tepat waktu, akurat, relevan dan dapat dipercaya, maka penggunaan sistem informasi manajemen harus benar-benar dilaksanakan sesuai dengan landasan sistem informasi manajemen.

\section{Efektivitas Kerja}

Konsep efektivitas dipergunakan untuk derajad pencapaian tujuan. Ada beberapa pengertian dan makna tentang keefektifan organisasi. Menurut Bernard, (1983 : 55), keefektifan organisasi diartikan sebagai pencapaian sasaran-sasaran dan usaha kooperatif. Georgopolous dan Tanneenbaun dalam Etzioni, (1964: 18), mengemukakan bahwa keefektivan organisasi sebagai keberhasilan organisasi diukur dari tingkat sejauh mana ia mencapai tujuannya dengan nilai organisasi dalam menunjukkan pencapaian tujuan. Kemudian Steers, (1964 : 18), mengemukakan bahwa keefektivan organisasi diukur dari sejauhmana ia mencapai tujuan yang layak dicapai.

Efektivitas merupakan konsep yang sangat penting karena mampu memberikan gambaran mengenai keberhasilan suatu organisasi dalam mencapai sasarannya. Efektivitas dapat diartikan sebagai pencapaian tujuan sesuai dengan rencana yang dibuat berdasarkan kebijakan yang telah ditetapkan dalam organisasi. Efektivitas juga dapat dilihat sejauh mana organisasi dapat melaksanakan seluruh tugas pokoknya mencapai semua sasaran. Pada kenyataannya, para anggota atau pegawai dalam suatu organisasi adalah merupakan faktor pengaruh yang paling penting atas efektivitas, karena prilaku anggota organisasi itulah yang dalam jangka panjang akan memperlancar atau merintangi tercapainya tujuan organisasi. Kesadaran akan sifat perbedaan pribadi yang terdapat diantara para pegawai sangat penting artinya karena para pegawai berbeda memberikan tanggapan dengan cara yang berbeda pula atas usaha-usaha manajemen untuk mencapai usaha yang diarahkan pada tujuan. Dengan mengetahui perbedaan ini, maka efektivitas akan dapat diukur melalui suatu sistem yang bekerja secara simultan dan sinergis.

Pembahasan mengenai efektivitas merupakan suatu konsep yang sangat luas dan lebih kompleks cakupannya. Efektivitas yang dimaksud dalam tulisan ini dilihat dari keberhasilan atau tingkat pencapaian tujuan dan sasaran yang berkaitan dengan pelaksanaan tugas-tugas kedinasan di Badan Pemberdayaan Masyarakat dan Pemerintahan Desa Provinsi Sulawesi Tenggara.

\section{Kerangka Pikir}

Berdasarkan kajian pustaka, maka penulis mengembangkan kerangka pikir untuk mempermudah proses penulisan karena mencakup tujuan dari penelitian itu sendiri. Tujuan dari penelitian ini adalah untuk mengetahui bagaimana kontribusi dan pengaruh Sistem Informasi Manajemen Terhadap Efektivitas Kerja Pegawai Badan Pemberdayaan Masyarakat dan Pemerintahan Desa Provinsi Sulawesi Tenggara.

Secara detil di uraikan bahwa Sistem Informasi Manajemen dapat berperan dalam menghasilkan informasi yang tepat waktu, akurat, relevan dan dapat dipercaya, maka penggunaan istem informasi manajemen harus benar-benar dilaksanakan sesuai dengan landasan dan model kerja sistem informasi manajemen. Terkait 
dengan tulisan ini, penulis menggunakan pendapat Hamalik (1993:25-27), sebagai alat ukur/indikator Sistem Informasi Manajemen. Mengemukakan dimensi sistem informasi manajemen sebagai berikut : Fungsionalisasi, (2) Keterpaduan, (3) Profesionalisme, (4) Mutu atau kualitas, (5) Pemerataan, (6) Koordinasi.

Demikian halnya dengan alat ukut atau indikator efeketivitas kerja pegawai, penulis menggunakan pendapat Zulkifli Amsyah (2003:131), mengemukakan beberapa indikator-indikator dari efektivitas kerja, yaitu :

1. Volume Pekerjaan, pengolahan data semakin banyak dan meluas sedangkan kapasitas pengolahan di banyak organisasi masih terbatas

2. Akurasi Hasil Pengolahan, informasi harus mencerminkan keadaan yang sebenarnya

3. Informasi Tepat Waktu, informasi itu harus tersedia atau ada pada saat informasi itu diperlukan

4. Peningkatan Biaya, peningkatan biaya personel dan bahan baku pemakaian komputer adalah sama dengan pada operasional pengolahan data nonkomputer.

Informasi kerangka pemikiran tulisan ini dijelaskan dengan ringkas pada Gambar l

\begin{tabular}{|c|c|}
\hline $\begin{array}{l}\text { Sistem Informasi Menejemen } \\
\text { 1. Fungsionalisasi } \\
\text { 2. Keterpaduan } \\
\text { 3. Profesionalisme } \\
\text { 4. Mutu atau Kualitas } \\
\text { 5. Pemerataan } \\
\text { 6. Koordinasi } \\
\text { Hamalik (1993) }\end{array}$ & 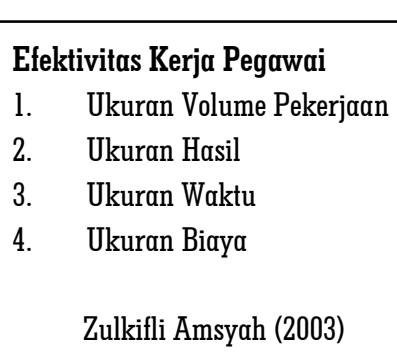 \\
\hline
\end{tabular}

Gambar l. Kerangka Pikir

\section{Hipotesis}

Berdasarkan kerangka pemikiran dan rumusan masalah tersebut, maka dapat disusun hipotesis kajian. Hipotesis ini berfungsi sebagai penuntun selama dalam penelitian (research-guide) rumusan hipotesanya adalah Sistem Informasi Manajemen berkontribusi dan memiliki berpengaruh signifikan terhadap efektivitas kerja pegawai pada Badan Pemberdayaan Masyarakat dan Pemerintahan Desa Provinsi Sulawesi Tenggara.

\section{METODE PENELITIAN}

\section{Desain Penelitian}

Penelitian ini menggunakan metode explanatory survey. Penggunaan metode ini karena penulis tidak hanya menggambarkan fakta-fakta empiris yang ditemui di lapangan, tetapi juga bermaksud menganalisis dan menjelaskan kontribusi dan pengaruh antar variabel yang akan menganalisis pengaruh variabel sistem informasi manajemen sebagai variabel bebas (independent variable) terhadap efektivitas kerja pegawai sebagai variabel terikat (dependent variable).

Pendekatan penelitian yang menggunakan pendekatan kuantitatif yang didukung oleh pendekatan kualitatif diarahkan untuk mampu mengungkap secara komprehensif hubungan antar sistem informasi manajemen dan efektivitas kerja pegawai pada Badan Pemberdayaan Masyarakat dan Pemerintahan Desa Provinsi Sulawesi Tenggara. 


JCunal publiuho is licensed under a Creative Commons Attribution 4.0 International License, which permits
unrestricted use, distribution, and reproduction in any medium, provided the original work is properly cited.

Teknik survey selanjutnya dapat digunakan untuk menganalisis hubungan-hubungan antar variabel dalam penelitian ini, yaitu hubungan antara variabel sistem informasi manajemen $(X)$ terhadap variabel efektivitas kerja pegawai pada Badan pemberdayaan Masyarakat dan Pemerintahan Desa Provinsi Sulawesi Tenggara (Y) dengan menggunakan data yang diperoleh dari sensus dengan menggunakan kuesioner sehingga akan nampak kontribusi varabel X terhadap variabel Y. secara detil di urakan dalam Tabel 2.

Tabel 2. Operasional Variabel:

\begin{tabular}{|c|c|c|}
\hline Variabel & Indikator & Item \\
\hline \multirow{6}{*}{$\begin{array}{l}\text { Sistem } \\
\text { informasi } \\
\text { manajemen }(X)\end{array}$} & 1. Fungsionalisasi & $\begin{array}{l}\text { a. Pengelolaan sistem informasi dilakukan oleh unit organisasi sesuai } \\
\text { fungsinya. } \\
\text { b. Pengelolaan sistem informasi dilakukan unit organisasi sesuai tugas }\end{array}$ \\
\hline & 2. Keterpaduan & $\begin{array}{l}\text { a. Sistem informasi dilaksanakan dengan memadukan unsur-unsur } \\
\text { keilmuan. } \\
\text { b. Keterpaduan dilaksanakan dengan cara melibatkan sub organisasi } \\
\text { terkait }\end{array}$ \\
\hline & 3. Profesionalisme & $\begin{array}{l}\text { a. Pemimpin dan pegawai mempunyai kemampuan dan keterampilan di } \\
\text { bidang informasi. } \\
\text { b. Para pegawai diikutsertakan dalam diklat yang diadakan organisasi }\end{array}$ \\
\hline & 4. Kualitas & $\begin{array}{l}\text { a. Pengelolaan sistem informasi berdasarkan prosedur kerja. } \\
\text { b. Informasi yang didapat sesuai dengan yang dibutuhkan. }\end{array}$ \\
\hline & 5. Pemerataan & $\begin{array}{l}\text { a. Informasi yang mendorong gerakan organisasi secara menyeluruh. } \\
\text { b. Penyebarluasan informasi dapat menjangkau semua sasaran dalam } \\
\text { organisasi. }\end{array}$ \\
\hline & 6. Koordinasi & $\begin{array}{l}\text { a. Pengelolaan sistem informasi dilakukan secara horizontal. } \\
\text { b. Pegawai diberikan bimbingan pelaksanaan kerja oleh pimpinan. } \\
\text { c. Pengelolaan sistem informasi dilakukan secara vertikal. }\end{array}$ \\
\hline \multirow{4}{*}{$\begin{array}{l}\text { Efektivitas Kerja } \\
\text { Pegawai (Y) }\end{array}$} & $\begin{array}{l}\text { 1. Ukuran Volume } \\
\text { Pekerjaan }\end{array}$ & $\begin{array}{l}\text { a. Pencapaian target tugas pokok pekerjaan. } \\
\text { b. Penambahan tugas tambahan diluar tugas pokok dan fungsi. }\end{array}$ \\
\hline & 2. Ukuran Waktu & $\begin{array}{l}\text { a. Pekerjaan diselesaikan sesuai dengan waktunya yang telah } \\
\text { ditetapkan. } \\
\text { b. Pemanfaatan waktu secara efisien. }\end{array}$ \\
\hline & 3. Ukuran Hasil & $\begin{array}{l}\text { a. Kualitas hasil pekerjaan yang baik. } \\
\text { b. Kuantitas hasil pekerjaan }\end{array}$ \\
\hline & 4. Ukuran biaya & $\begin{array}{l}\text { a. Penggunaan biaya sesuai dengan kebutuhan. } \\
\text { b. Pembuatan pelaporan pertanggungjawaban anggaran. }\end{array}$ \\
\hline
\end{tabular}

\section{Populasi dan Sampel}

Populasi dalam penelitian ini adalah seluruh Pegawai Negeri Sipil pada Badan Pemberdayaan Masyarakat dan Pemerintahan Desa Provinsi Sulawesi Tenggara yang berjumlah 93 orang. Sampel dalam penelitian ini adalah mengambil seluruh populasi (sampel jenuh) yaitu 48 orang responden.

\section{Prosedur Pengumpulan Data}

Prosedur pengumpulan data yang digunakan dalam penelitian ini adalah: 1) Kuesioner: Untuk memperoleh data mengenai variabel-variabel penelitian ini yaitu, variabel bebas $\mathrm{X}$, dan variabel tak bebas $\mathrm{Y}$ dilakukan dengan melalui daftar pertanyaan dan pernyataan yang akan dijawab oleh responden; 2) wawancara: merupakan instrumen pelengkap dengan menentukan beberapa informan kunci (key informant) yang menjadi 
bahan cross-check terhadap data kuesioner dengan menggunakan pedoman wawancara (interview guide); 3) Dokumentasi: melakukan pengumpulan data skunder yang diperlukan untuk menunjang penelitian ini dengan studi dokumentasi peneliti akan mengumpulkan buku, jurnal atau sumber-sumber ilmiah lainnya. Selanjutnya Pengukuran data pada variabel bebas dilakukan dengan memberi jenjang terhadap gejala yang diukur dengan menggunakan skala likert, terhadap sejumlah persetujuan, responden akan diminta untuk menyatakan persetujuannya yang terkategori dalam macam jawaban, yaitu Sangat Setuju, (SS), " Setuju" (S), "Ragu-ragu" (R), "Tidak Setuju" (TS), dan " Sangat Tidak Setuju" (STS). kemudian data yang diperoleh akan dilakukan Uji Validitas dan Reliabitas.

\section{Teknik Analisis Data}

Untuk menguji hipotesis yang diajukan, digunakan teknik analisis melalui Regresi Sederhana untuk mengetahui bentuk pengaruh antara variabel Bebas $(X)$ yaitu sistem informasi manajemen dan variabel tak bebas (Y) yaitu efektivitas kerja pegawai pada Badan Pemberdayaan Masyarakat dan Pemerintahan Desa Provinsi Sulawesi Tenggara (Y).

$$
\begin{aligned}
& \mathrm{Y}=\mathrm{a}+\mathrm{bX} \\
& \text { Keterangan : } \\
& \mathrm{a}=\text { Nilai konstan } \\
& \mathrm{b}=\text { Koefisien Regresi } \\
& \mathrm{X} \quad=\text { Nilai variabel bebas } \\
& \mathrm{Y} \quad=\text { Nilai variabel terikat }
\end{aligned}
$$

\section{PEMBAHASAN}

\section{Hasil Pengujian Hipotesis}

Penelitian dilakukan terhadap 48 orang responden pada Badan Pemberdayaan Masyarakat dan Pemerintahan Desa Provinsi Sulawesi Tenggara. Penelitian ini menurunkan hipotesis penelitian sebagai berikut : Sistem Informasi manajemen berpengaruh terhadap efektivitas kerja pegawai di Badan Pemberdayaan Masyarakat dan Pemerintahan Desa Provinsi Sulawesi Tenggara.

Hasil pengujian hipotesis, dengan menggunakan program SPSS versi 15,00 adalah :

1. Persamaan regrasi, sebagai berikut :

$$
\hat{Y}=1.187+1.203 X
$$

Hal ini berarti sebelum variabel Sistem Informasi Manajemen mempengaruhi kualitas kerja pegawai ternyata nilai konstanta kualitas kerja sudah ada sebesar l.187.

2. Berdasarkan hasil pengujian signifikansi diperoleh nilai $t_{\text {hitung }}=7.4166$ lebih besar dari pada nilai $t_{\text {tabel }}=$ 1.5457, Hal ini menunjukkan bahwa sesuai kriteria pengujian bahwa jika $t_{\text {hitung }}$ lebih besar dari $t_{\text {tabtel }}$ maka $\mathrm{H}_{0}$ ditolak atau $\mathrm{H}_{1}$ diterima dengan taraf kepercayaan 95 persen $(\alpha=0.05)$. Ini menunjukan bahwa Sistem Informasi manajemen tidak berpengaruh terhadap efektivitas kerja pegawai di Badan Pemberdayaan Masyarakat dan Pemerintahan Desa Provinsi Sulawesi Tenggara.

2. Kemudian hasil pengujian koefisien Korelasi Spearman-Brown menunjukkan koefisien korelasi ( $\mathrm{r}$ ) sebesar 0.4896 nilai hubungan tersebut menunjukan bahwa variabel Sistem Informasi manajemen tidak berpengaruh terhadap efektivitas kerja pegawai di Badan Pemberdayaan Masyarakat dan Pemerintahan Desa Provinsi Sulawesi Tenggara. 
3. Koefisien determinasi $\left(\mathrm{R}^{2}\right)$ adalah sebesar 0.6120 yang berarti besarnya sumbangan variabel Sistem Informasi Manajemen berpengaruh terhadap efektivitas kerja pegawai di Badan Pemberdayaan Masyarakat dan Pemerintahan Desa Provinsi Sulawesi Tenggara sebesar 61,20 persen.

Tabel 3. Hasil Pengujian Hipotesis

\begin{tabular}{|l|l|c|c|}
\hline \multicolumn{1}{|c|}{ Variabel } & $\begin{array}{c}\text { Koefisien } \\
\text { Regresi (b) }\end{array}$ & $\begin{array}{c}\mathrm{t} \text { hitung } \\
\mathrm{db}=124\end{array}$ & $\begin{array}{c}\text { Probabilitas } \\
\text { Parsial (P) }\end{array}$ \\
\hline Sistem Informasi Manajemen X & 1.203 & 7.41665 & 0,000 \\
\hline Constanta (a) & $1.187: \mathrm{t}$ sig $=0,832$ \\
Korelasi sederhana (R) & 0.4896 & \\
Koefisien determinasi (R & 0.612 & \\
Square) & 7.41665 & \\
Probabilitas Simultan & 0.000 & \\
Error & 2.4336 & \\
\hline
\end{tabular}

Sumber : Hasil Pengolahan data, 2018-04-16

Hasil pengujian reliabilitas untuk variabel Sistem Informasi Manajemen yang terdiri atas Fungsionalisasi $\left(\mathrm{X}_{1}\right)$ Keterpaduan $\left(\mathrm{X}_{2}\right)$,Profesionalisme $\left(\mathrm{X}_{3}\right)$ Patuh dalam menggunakan/ Memelihara Perlengkapan Kantor $\left(\mathrm{X}_{4}\right)$, Pemerataan $\left(\mathrm{X}_{5}\right)$ Koordinasi $\left(\mathrm{X}_{6}\right)$ dengan menggunakan metode belah dua spilt-half dapat dilihat pada tabel 4.

Tabel 4. Hasil Pengujian Hipotesis Variabel Sisten Informasi Manajemen dan Efeketivitas

\begin{tabular}{|c|r|r|r|r|r|c|}
\hline Dimensi & \multicolumn{1}{|c|}{$\mathrm{r}_{\mathbf{X}}$} & \multicolumn{1}{c|}{$\mathrm{r}_{\mathrm{sb}}$} & \multicolumn{1}{c|}{$\mathrm{t}_{\text {hitung }}$} & \multicolumn{1}{c|}{$\mathrm{T}_{\text {tabel }}$} & Keterangan & Kesimpulan \\
\hline $\mathbf{X}_{\mathbf{1}}$ & 0.298 & 0.459 & 4.067 & 1.890 & Signifikan & Reliabel \\
$\mathbf{X}_{\mathbf{2}}$ & 0.688 & 0.815 & 11.070 & 1.890 & Signifikan & Reliabel \\
$\mathbf{X}_{\mathbf{3}}$ & 0.479 & 0.648 & 6.696 & 1.890 & Signifikan & Reliabel \\
$\mathbf{X}_{\mathbf{4}}$ & 0.609 & 0.757 & 9.127 & 1.890 & Signifikan & Reliabel \\
$\mathbf{X}_{\mathbf{5}}$ & 0.378 & 0.567 & 5.465 & 1.890 & Signifikan & Reliabel \\
$\mathbf{X}_{6}$ & 0.466 & 0.635 & 6.683 & 1.890 & Signifikan & Reliabel \\
\hline Variabel & $\mathrm{r}_{\mathbf{X}}$ & $\mathrm{r}_{\mathrm{sb}}$ & $\mathrm{t}_{\text {hitung }}$ & $\mathrm{T}_{\text {tabel }}$ & Keterangan & Kesimpulan \\
\hline $\mathbf{Y}$ & & & & & & Reliabel \\
\hline
\end{tabular}

Sumber : Hasil Pengolahan data, 2018-04-16

Pada bagian pembahasan akan di jelaskan berdasar indikator sesuai karangka pikir penelitian dan secara ringkas di uraikan sebagai berikut:

\section{Dimensi Fungsionalisasi}

hasil temuan di lapangan menunjukan bahwa fungsionalisasi pada Badan Pemberdayaan Masyarakat dan Pemerintahan Desa Provinsi Sulawesi Tenggara masih perlu ditata agar pengelolaan sistem informasi manajemen oleh unit organisasi sesuai fungsi dan tugasnya. Fungsionalisasi dalam sistem informasi manajemen 
dapat dilakukan dengan pembagian tugas yang seimbang sesuai dengan tugas, wewenang dan tanggungjawabnya. Selain itu kemampuan pegawai perlu mendapat perhatian agar pegawai dalam menjalankan fungsi dan tugasnya dengan baik.

Berdasarkan uraian tersebut, peneliti dapat mengemukakan bahwa dimensi fungsionalisasi dalam sistem informasi manajemen Pada Badan Pemberdayaan Masyarakat dan Pemerintahan Desa Provinsi Sulawesi Tenggara baik secara teoritik maupun empirik telah memberikan pengaruh yang signifikan terhadap efektivitas kerja pegawai Pada Badan Pemberdayaan Masyarakat dan Pemerintahan Desa Provinsi Sulawesi Tenggara.

Kemudian, apabila melihat besarnya pengaruh yang dihasilkan sebagaimana yang telah dijelaskan tersebut, dimensi fungsionalisasi ini dapat dikatakan memberikan pengaruh dalam konteks sistem informasi manajemen meskipun kecil yaitu sebesar 8,116\%. Oleh karena itu, dimensi fungsionalisasi ini perlu mendapat perhatian yang memadai baik dari Kepala Badan Pemberdayaan Masyarakat dan Pemerintahan Desa Provinsi Sulawesi Tenggara maupun dari para pegawainya.

\section{Keterpaduan}

Dimensi keterpaduan memberikan pengaruh yang cukup besar, yaitu sebesar $25,766 \%$. Untuk itu dimensi keterpaduan perlu mendapat perhatian dari semua pihak terutama dari unsur pimpinan, karena jika dimensi keterpaduan ini kurang mendapatkan perhatian, maka dapat berimplikasi pada efektivitas kerja Pada Badan Pemberdayaan Masyarakat dan Pemerintahan Desa Provinsi Sulawesi Tenggara secara keseluruhan.

Hasil analisis di atas dikuatkan oleh jawaban responden yang pada umumnya memberikan penilaian yang cukup baik terhadap upaya Badan Pemberdayaan Masyarakat dan Pemerintahan Desa Provinsi Sulawesi Tenggara dalam melaksanakan keterpaduan melalui memadukan unsur-unsur keilmuan dan melibatkan sub organisasi terkait dalam pengelolaan sistem informasi manajemen. Sesuai pula dengan hasil wawancara dengan Kepala Badan Pemberdayaan Masyarakat dan Pemerintahan Desa Provinsi Sulawesi Tenggara bahwa keterpaduan diupayakan diciptakan lewat kebersamaan antara unsur pimpinan dan bawahannya. Hal ini dilakukan dari mulai tahap perencanaan, pelaksanaan maupun tahap evaluasi dan semua kegiatan dalam organisasi sehingga para pegawai merasa menjadi bagian dalam organisasi Badan Pemberdayaan Masyarakat dan Pemerintahan Desa Provinsi Sulawesi Tenggara.

\section{Profesionalisme}

Hasil uji statistik sebagaimana dijelaskan tersebut memperlihatkan bahwa dimensi profesionalisme dalam sistem informasi manajemen telah memberikan pengaruh yang signifikan terhadap efektivitas kerja pegawai Badan Pemberdayaan Masyarakat dan Pemerintahan Desa Provinsi Sulawesi Tenggara. Pernyataan di atas sesuai temuan penelitian menunjukan bahwa pada umumnya pegawai mengakui bahwa aktivitas mereka sangat berperan dalam menciptakan profesionalisme kerja mereka. Indikasi ini dikuatkan oleh hasil jawaban responden yang menunjukan nilai kategori cukup dan memiliki kecenderungan ke arah yang lebih baik. Kondisi ini terjadi akibat dari profesionalisme pegawai pada Badan Pemberdayaan Masyarakat dan Pemerintahan Desa Provinsi Sulawesi Tenggara tidak terlepas dari peran Kepala Badan Pemberdayaan Masyarakat dan Pemerintahan Desa Provinsi Sulawesi Tenggara dalam memotivasi para pegawai sehingga mereka dapat melakukan tugas-tugasnya dengan rasa tanggung jawab, sekalipun hasil uji statistik menunjukan profesionalisme memberikan pengaruh yang cukup signifikan yaitu sebesar $10,134 \%$. walaupun dimensi profesionalisme ini memberikan pengaruh yang kecil bila dibandingkan dengan dimensi lain. 


\section{Mutu Atau Kualitas}

Berdasarkan hasil wawancara, dimensi mutu atau kualitas dalam sistem informasi manajemen baik secara teoritik dan empirik telah memberikan pengaruh yang signifikan terhadap efektivitas kerja pegawai pada Badan Pemberdayaan Masyarakat dan Pemerintahan Desa Provinsi Sulawesi Tenggara. Mutu atau kualitas memberikan pengaruh yang cukup signifikan yaitu sebesar 30,996 \%. Oleh karena itu, dimensi mutu atau kualitas sistem informasi manajemen cuku besar memberikan pengaruh terhadap efektivitas kerja pegawai pada Badan Pemberdayaan Masyarakat dan Pemerintahan Desa Provinsi Sulawesi Tenggara bila dibandingkan dengan dimensi-dimensi lainnya. Untuk itu Kepala Badan hendaknya memberikan perhatian yang serius terhadap mutu atau kualitas sistem informasi manajemen pada Badan Pemberdayaan Masyarakat dan Pemerintahan Desa Provinsi Sulawesi Tenggara. Karena jika Kepala Badan kurang memperhatikan dimensi ini, secara operasional dapat bisa mengganggu terhadap keberhasilan tujuan organisasi.

\section{Pemerataan}

Hasil uji statistik sebagaimana dijelaskan tersebut memperlihatkan bahwa dimensi pemerataan dalam sistem informasi manajemen telah memberikan pengaruh yang signifikan terhadap efektivitas kerja pegawai pada Badan Pemberdayaan Masyarakat dan Pemerintahan Desa Provinsi Sulawesi Tenggara dan hasil wawancara menunjukan bahwa pada umumnya pegawai mengakui bahwa upaya pemerataan penerimaan informasi yang diterima pegawai dalam rangka pelaksanaan tugas-tugasnya sudah dilakukan meskipun belum menunjukkan hasil yang optimal. Selain itu upaya penyebarluasan informasi telah dilakukan dengan melalui berbagai media baik tertulis maupun secara lisan melalui briefing. Indikasi ini dikuatkan oleh hasil jawaban responden sebagaimana dijelaskan tersebut yang menunjukan nilai kategori cukup.

\section{Koordinasi}

Hasil uji statistik sebagaimana dijelaskan tersebut memperlihatkan bahwa dimensi koordinasi telah memberikan pengaruh yang signifikan terhadap efektivitas kerja pegawai pada Badan Pemberdayaan Masyarakat dan Pemerintahan Desa Provinsi Sulawesi Tenggara.

Hasil temuan penelitian menunjukan bahwa pada umumnya pegawai mengakui bahwa koordinasi aktivitasnya sangat berperan dalam menciptakan efektivitas kerja mereka. Indikasi ini dikuatkan oleh hasil jawaban responden sebagaimana dijelaskan tersebut yang menunjukan nilai kategori cukup dan memiliki kecenderungan ke arah yang lebih baik. Hal ini didukung oleh pendapat Simon, (1982:168) mengemukakan, dipandang dari kedudukan si individu di dalam organisasi, koordinasi melibatkan beberapa unsur : hubungan tujuan-tujuan si individu dan tujuan-tujuan antara dengan bagian-bagian lain dalam organisasi; penilaian si individu mengenai alternatif-alternatif yang tersedia baginya dan bagi anggota-anggota lainnya di dalam kelompok itu : dan dugaan-dugaannya sehubungan dengan arah-arah tindakan yang diikuti oleh yang lainnya.

Kemudian, apabila melihat besarnya pengaruh yang dihasilkan (sebagaimana telah dijelaskan tersebut), Sub variabel ini memberikan pengaruh yang cukup signifikan yaitu sebesar 53,802\%. Dengan angka tersebut menunjukan bahwa koordinasi sebagai salah satu pembentuk variabel sistem informasi manajemen, yang mempunyai pengaruh yang cukup signifikan terhadap efektivitas kerja pegawai pada Badan Pemberdayaan Masyarakat dan Pemerintahan Desa Provinsi Sulawesi Tenggara. 


\section{KESIMPULAN}

Berdasarkan hasil analisis data pembahasan maka penulis menarik simpulan penelitian bahwa

1. Ada pengaruh sistem informasi manajemen pada Badan Pemberdayaan Masyarakat dan Pemerintahan Desa Provinsi Sulawesi Tenggara terhadap efektivitas kerja pegawai. Pengaruh tersebut mengindikasikan bahwa sistem informasi manajemen memiliki pengaruh cukup tinggi terhadap efektivitas kerja kerja pegawai pada Badan Pemberdayaan Masyarakat dan Pemerintahan Desa Provinsi Sulawesi Tenggara.

2. Pengaruh Sistem Informasi Manajemen terhadap efektifitas kerja pegawai pada Kantor Badan Pemberdayaan Masyarakat dan Pemerintahan Desa Provinsi Sulawesi Tenggara sebesar 61.20 \% .Hasil analisis tersebut menunjukan bahwa keenam dimensi sistem informasi manajemen : fungsionalisasi, keterpaduan, profesionalisme, mutu atau kualitas, semuanya menunjukan pada kisaran cukup berpengaruh. Hal ini menunjukan bahwa sistem informasi manajemen sudah dilaksanakan meskipun belum optimal.

\section{DAFTAR PUSTAKA}

Amsyah, Zulkifli. 2005. Manajemen Sistem Informasi. Jakarta: PT. Gramedia Pustaka Umum.

Hamalik, Oemar. 1993. Pengelolaan Sistem Informasi. Bandung: PT. Tri Genda Karya.

Kast, Fremont E. and James E. Rosenzweig. 1990. Organization And Management : A System And Contigency Approach, McGraw-Hill International Book Company : Tokyo.

Murdick, Robert G., dan Ross, 1971. Information Systems for modern Management, Prentice-Hall, Inc., Englewood Cliffs, N.J.

Steers, Richard. 1990. Efektivitas Organisasi. (Terjemahan Magdalena). Jakarta : Erlangga. 